\title{
Conflicts in the land use in mountainous territories
}

\author{
Zaur Ivanov $^{1 *}$, Alim Gurtuev ${ }^{1}$, Zara Kunasheva ${ }^{2}$, and Zukhra Khocheva $^{2}$ \\ ${ }^{1}$ Kabardino-Balkarian Scientific Center of the Russian Academy of Sciences, Institute for Computer \\ Science and Problems of Regional Management, I.Armand st., 37a, 360004, Nalchik, Russia \\ ${ }^{2}$ Kabardino-Balkarian State Agrarian Economic University, Lenina st., 1v, 360030, Nalchik, Russia
}

\begin{abstract}
The purpose of the study is to determine the causes of conflicts in the land use in land-hungry regions and to develop optimal solutions in land disputes. The research is based on the field data, collected in landhungry regions of Russian Caucasus and historical data for same regions. We analyze the data acquired and use the system approach for developing a classification for studied conflicts. It supports the thesis that the agricultural land ownership is critical for the development of a stable regional system of agricultural production. In the majority of Russian regions land reform has been already carried out. Thus, market mechanisms for the functioning and realization of the right to use and possession of agricultural land are in effect. But in North Caucasus republics, institutionalization of land ownership is still vague. As a result, the number of disputes and conflicts in land use is growing. In the article, we carried out a classification of conflicts in land use and the analysis of land conflicts in the republics of the North Caucasus.
\end{abstract}

\section{Introduction}

Land is one of the most valuable assets of every nation. The study of theoretical and practical aspects of the organization of limited land resources distribution leads to the understanding that land is not just a type of resource, but a national asset that must be preserved as a guarantee of the well-being of current and future generations. [1-3]

Land reform has been carried out in most regions of the Russian Federation, where market mechanisms for the functioning and implementation of the right to use and own agricultural land are effective. There is also a global experience of successful land reform in land-hungry countries (for example, Israel, with a population of more than 8 million people, has only 440 thousand hectares of arable land, but exports food) [4-6]. For the formation of the land relations institute in land-hungry mountain regions, it is necessary to ensure and protect the interest of conservation, reproduction and efficient use of land resources as the main national wealth. The problem is the adequate perception of the land reform by the public to change the title of ownership, the mechanisms of distribution and redistribution of land, so conflicts often arise.[7-9] People often just don't understand what land ownership is. It's not a thing,

\footnotetext{
* Corresponding author: zaurivanov@mail.ru
} 
it's not an object, and you can't take it with you. This is the right to use the particular part of the land with some specific restrictions, and nothing more.

Given the severity and risks of various conflicts, land reform cannot be implemented except for the "technology of social compromise" (when the results of the reform are satisfied with the vast majority of the population). Given that the highest form of democracy is the expression of the will of the people through democratic elections, we recommend holding a referendum that will determine the mood of society and its attitude to the reform of land relations.

\section{Materials and methods}

In the regions of the North Caucasus historically agricultural character of the way of life of the majority population, multinational companies, as well as the real gap between the level of institutional development of the economy, lack of successful experiences of land reform, as a result of growing number of conflicts in land use. An important theoretical aspect of choosing the mechanism for distributing farmland in land reform is the inherent conflict of the distribution process itself - participants ' ideas about fair distribution are different and conflict with each other. Therefore, forecasting strategies of distribution participants should be based on the provisions of the economic theory of conflicts [10], and the choice of distribution mechanisms should take into account the related problems of identifying preferences.

Conflicts arising in the land use of mountainous areas of the North Caucasus can be divided into the following groups:

1. Disputes between Federal and regional authorities;

2. Conflicts between regions of the North Caucasus;

3. Conflicts between municipalities of the same Federal subject;

4. Conflicts between local populations and ethnic enclaves;

5. Conflicts between indigenous peoples;

6. Conflicts between the local population and municipal authorities;

7. Conflicts between local populations and large land users;

8. Conflicts between residents of the same municipality;

9. Rejection of Federal and regional laws "on land" by the local population.

\subsection{Disputes between Federal and regional authorities}

In the republics of the North Caucasus, it is necessary to conduct an inventory of available land resources, with the differentiation of Federal, regional and municipal property. After all, each locality or hectare of land is tax collections to the regional Treasury or, on the contrary, deductions from it. Given the administrative resources of the Federal authorities and the levers of influence on regional authorities, it is clear that regions often lose land disputes. Until now, about $10 \%$ of the area of the mountain territories of the North Caucasus Federal district has no status and disputes continue. This situation has a negative impact on the development of regional agriculture, the competitiveness of agricultural producers and the investment attractiveness of the republics.

\subsection{Conflicts between the regions of the North Caucasus}

Currently, more than ten land (territorial) disputes between regions are known on the territory of the Russian Federation. The following territorial disputes have been recorded in the North Caucasus: between Ingushetia and North Ossetia, Ingushetia and Chechnya, Chechnya and Dagestan, the CBD and the KCR. In the 90s, conflicts between the republics of the North Caucasus Federal district reached a military confrontation, with a large number of dead and forced migrants. According to the Constitution of the Russian Federation, it is the Federation 
Council that approves agreements between subjects on borders. Borders between subjects of the Russian Federation can be changed by mutual consent. In the 90's, territorial conflicts in the Russian Federation had ethnic and religious causes, and in the 2000s, subjects argued over economic and recreational facilities. Disputes occur over boundaries between the regions are caused by errors of the cartographers. During the Soviet period, multinational republics were formed (for example, the Chechen-Ingush Autonomous Soviet socialist Republic) and for a long time there was a "diffusion" of indigenous peoples and their habitats, driving people into collective enterprises. In the socialist system, everything was common, in our time, "parting" has become painful for many of them.

In 2019, the regional authorities of Chechnya and Ingushetia agreed on the disputed territories. Citizens living in disputed territories experience many inconveniences when applying for regional benefits, tax deductions, child allowances, etc. However, the Russian Federation still does not have a well-established mechanism for resolving territorial disputes between regions. Therefore, many territorial disputes are frozen.

\subsection{Conflicts between municipalities of the same Federal subject}

After the republics of the North Caucasus gained sovereignty, the administrative and territorial structure of the regions changed. In some cases, the number of municipal districts has increased, and in some cases, districts have been enlarged. there are examples of merging neighboring villages into one municipality. Federal law No. 131-FZ" on General principles of local self-government organization in the Russian Federation", signed by the President on October 6, 2003, obliged the authorities of all subjects of the Russian Federation to establish the borders of municipalities in accordance with the new requirements by January 1, 2005 and to grant the respective municipalities one of the following statuses: urban settlement, rural settlement, municipal district, urban district, as well as inner-city territory. A village community could be one or several United General territory of rural settlements (villages, villages, villages, hamlets). An urban settlement could be a city or an urban-type settlement with an adjacent territory (rural localities that are not rural settlements can also be part of an urban settlement). Several settlements and inter-settlement territories United by a common territory became a municipal district. An urban district is an urban settlement that is not part of a municipal district. An inner-city territory is a part of a city of Federal significance that is a municipal entity. All other inner-city municipalities were to be abolished by January 1 , 2006. As a result, dozens of land disputes over the definition of borders between municipal districts and rural settlements. Administrative borders between municipalities are approved by The Parliament of the Federal subject. But, often parliamentarians do not want to take responsibility and many land disputes between municipalities remain unresolved. If the state authorities of the subject do not fulfill them by this date, the Federal Executive authorities will take care of this.

\subsection{Conflicts between local populations and ethnic enclaves.}

The evolution of the settlement of mountain peoples over the past two hundred years has a complex architecture. The areas of residence of indigenous backgammon were violated, and a crucial role was played in this:

1) the Russian-Caucasian war;

2) World War I;

3) the Great October socialist revolution;

4) Civil war in Russia;

5) formation of multinational autonomous republics;

6) World War II;

7) deportation of peoples and their return to their historical homeland;

8) the collapse of the Soviet Union;

9) hot conflicts of the 90 's; 
10) formation of national sovereign republics with ethnic enclaves (examples: Cossack villages in the republics, Balkar villages in the Tersk district of the CBD, Ingush settlements in Chechnya and North Ossetia, etc.).

As a result, conflicts in land use are often recorded, and there are cases when agricultural machinery, crops, and cattle were taken away. In the 90s, in the Tersk district of the CBD, there was an attempt to capture the Balkar enclave - the village of New Balkaria by Kabardians, who divided the Balkar households among themselves. And only the harsh reaction of the authorities returned the Balkars to their homes.

\subsection{Conflicts between indigenous peoples.}

Artificial municipal borders formed during the Soviet period, without taking into account the habitat of indigenous peoples, worked like time bombs. Also, collective farms located in mountainous areas were given arable land on the plain to strengthen the forage base, without taking into account the territories of indigenous peoples (at that time everything was common, national and state). Most collective enterprises ceased to exist in the 1990s, with the exception of state and municipal unitary agricultural enterprises in Chechnya[11]. And the problems of land use, determining the status and owner of land plots that were once transferred for use have not been resolved. On this basis, conflicts between the indigenous peoples of the regions (in Kabardino-Balkaria, Karachay-Cherkess Republic, etc.) are recorded.

In multinational entities, any redistribution of land between conditional ethnic groups and a new administrative-territorial structure is accompanied by conflict situations. Often, the current government leaves these land disputes and conflicts as a legacy to future generations. History will show how dangerous this is.

\subsection{Conflicts between the local population and municipal authorities.}

In modern Russia, there have been many attempts to reform agricultural enterprises and land relations. In the republics of the North Caucasus Federal district (except Chechnya), in accordance with Federal programs, the names of collective agricultural enterprises were changed without intra-organizational changes (collective shared agricultural enterprises KDSHP, collective shared enterprises - KDP, agricultural cooperative-SHP, people's enterprise of workers-NPR, etc.). As a result, in the 2000s, most collective enterprises were agricultural producers only on paper, and agricultural land was processed by the local population on a rental basis. The Soviet land use system was destroyed, but a new one was not created. [12]

For a long time (until 2015), the decision to lease certain areas to specific economic agents was decided by the municipal government. This led to an unfair distribution of the best agricultural land plots. with the help of administrative resources, the municipal authorities and the" rural elite " received significant areas of arable land with the best economic, geographical, and natural and biological characteristics. At the same time, the interests of the local population were not taken into account - rural residents per household could not rent more than 2 hectares for one growing season, which led to an increase in social tension.

Also, there is tension between the municipal authorities and the local population over the implementation of article 10 of the Federal law "on turnover of agricultural land", according to which municipal land is leased through auctions. In recent years, auction mechanisms have become a legal way for "oligarchs" to seize plots of financially weaker economic agents (tenants). Using loopholes in land law, the winner of the auction through the courts seeks a revaluation of the usage fee and lease terms. In this situation, improving the auction mechanisms has become a necessity.

\subsection{Conflicts between local populations and large land users.}


Most large agricultural producers in the past are managers of collective enterprises or the socalled "rural elite" (people close to the government or the government itself). This category of land users received significant areas of arable land (up to 10,000 hectares) not quite fair way, while the majority of the rural population can not get even a hectare of arable land for rent. Given the unemployment rate in rural settlements in mountainous areas and the limited land resources, local discontent is growing. There is a desire for people to take everything away and divide it fairly. This situation will continue until the land reform is carried out, taking into account the interests of all agricultural producers and the local population. Given example. In the CBD, 158 hectares of mountain pastures were put up for auction - the Kurata tract in the state enterprise "Aursenth". The starting price for 1 ha set by the Republic is 96106 rubles. The starting price of the lot with all the buildings is 27 thousand rubles. There were only two participants in the open auction. during the auction, the price was raised to 2 million rubles, and the first participant became the winner. After some time, the auction results were canceled and a second auction was scheduled, while the starting price of the lot was much lower. At repeated auctions, one buyer was registered - the first participant of the previous auction, who purchased this lot with one step for 27 thousand rubles. A limited number of people knew about the auction in Kabardino-Balkaria. For the local population, this is a bad signal that the villagers may be left without farmland. [13]

\subsection{Conflicts between residents of the same municipality.}

Often there are disputes and conflicts between residents of the same municipality in land use. Until now, people remember their ancestral allotments and can't get used to other people using these plots. When conducting auctions, there are attempts by some people to take away land plots from tenants, raising the cost of the lot, which end in conflicts. Wealthier people and citizens with administrative resources use the most fertile land with a favorable location. The uneven distribution of resources often leads to conflicts that sometimes escalate into violence. For example, many were tempted to settle accounts with those who once received land holdings in a less than honest way and represented the "middle layer of the corrupt system" associated with the previous government.

There are disputes and conflicts in land use due to mapping errors. In the republics of the North Caucasus Federal district, according to local authorities, only $61 \%$ of agricultural land is registered in the cadastral register. In Russian legislation, there is no obligation of the owner to form a land plot and put it on cadastral registration, while budget funding for these works has never been provided. Land plots that are not registered in the cadastral register are not taxed, and rent is not paid to the budget for them, i.e. they are not involved in economic turnover. There are also conflicts between residents of the same municipality over roads, water resources, access to electricity and electricity networks, etc.

\subsection{Rejection of Federal and regional land laws by the local population.}

The problem is an adequate public perception of land reform to change the title of ownership and land distribution mechanisms. There is currently a scientific and practical discussion on the mechanism for determining the size and distribution of agricultural land that requires a separate discussion.

Rural areas of the North Caucasus Federal district are characterized by a traditional society that does not accept new laws and rules of market relations, auction mechanisms for the distribution and redistribution of land resources.

A person has been working on a certain piece of land on a rental basis for a long time, and after the lease period, the land is put up for auction. The tenant does not understand why he must win the auction in order to prolong the lease agreement. For him, these are unplanned additional expenses. Also, tenants are dissatisfied with the fact that the lease term depends on the production direction (crop production - up to 7 years, gardening - up to 25 years). The 
state puts tenants in unequal conditions. A tenant who grows grain must participate in auctions every 7 years.

In recent years, the number of tenants has been growing and in the republics of the North Caucasus, their number is more than 30 thousand agricultural producers. As a result, competition between tenants is growing. As the experience of previous years shows, the existing land law is not a universal tool for land reform. The role of customary law institutions in regulating land use has increased significantly. [14, 15] Therefore, it is necessary to improve the existing legal framework "on land" in the subjects of the North Caucasus.

Despite the similarity of customary law rules governing land use in the KabardinoBalkarian Republic and the Karachay-Cherkessia Republic, the conceptual basis for land reform in these republics is different. The experience of the KCR shows that land reform is not accompanied by a significant surge in social conflicts.

\section{Results and conclusion}

In the republics of the North Caucasus Federal district, there are two concepts of land reform: on the basis of privatization and on the basis of long-term lease. At the same time, it should be noted that the system of land distribution based on long-term lease immanently contains the basis for economic and social conflicts related to the uncertainty of the amount of rent in the long term. Another drawback of the rental system of land distribution in the mountainous territories of the North Caucasus is associated with a high level of corruption. Proponents of the rental system, in turn, point to the social justice of the lease (the land is owned by all residents), the inefficiency and technological backwardness of small forms of management in the agricultural sector, the formation of an additional revenue base of local budgets, and also note the danger of corruption during privatization. In this situation, it can be concluded that there is currently no real alternative to private land ownership as a conceptual basis for land reform.

As a result we propose a classification of conflicts and disputes in the land use of the mountainous territories of the North Caucasus. It based on analysis of the nature of land disputes and suggested possible ways to resolve them in the republics of the North Caucasus Federal district. These results are summarized in the following table.

Table 1 - Nature of land conflicts and ways to resolve them

\begin{tabular}{|c|l|l|l|}
\hline № & Classification of conflicts. & $\begin{array}{l}\text { The nature of land conflicts in the } \\
\text { North Caucasus Federal district. }\end{array}$ & Ways to resolve disputes. \\
\hline 1 & $\begin{array}{l}\text { Disputes between Federal } \\
\text { and regional authorities }\end{array}$ & $\begin{array}{l}10 \% \text { of the area of the mountain } \\
\text { territories of the North Caucasus } \\
\text { Federal district does not have the } \\
\text { status (owner) }\end{array}$ & $\begin{array}{l}\text { Inventory of land and } \\
\text { division into Federal, } \\
\text { regional and municipal } \\
\text { property. }\end{array}$ \\
\hline 2 & $\begin{array}{l}\text { Conflicts between the } \\
\text { regions of the North } \\
\text { Caucasus. }\end{array}$ & $\begin{array}{l}\text { In the USSR, multinational } \\
\text { republics were formed and for a } \\
\text { long time there was a "diffusion" } \\
\text { of indigenous peoples and their } \\
\text { habitats. }\end{array}$ & $\begin{array}{l}\text { Development of a } \\
\text { mechanism for resolving } \\
\text { territorial disputes between } \\
\text { regions }\end{array}$ \\
\hline 3 & $\begin{array}{l}\text { Conflicts between } \\
\text { municipalities of the same } \\
\text { Federal subject. }\end{array}$ & $\begin{array}{l}\text { New administrative and territorial } \\
\text { structure of regions. }\end{array}$ & $\begin{array}{l}\text { Development of a } \\
\text { mechanism for resolving } \\
\text { territorial disputes in the } \\
\text { region. }\end{array}$ \\
\hline 4 & $\begin{array}{l}\text { Conflicts between local } \\
\text { populations and ethnic } \\
\text { enclaves. }\end{array}$ & $\begin{array}{l}\text { Evolution of settlement of } \\
\text { mountain peoples over the past } \\
\text { two hundred years. }\end{array}$ & $\begin{array}{l}\text { Joint work of the } \\
\text { authorities, representatives } \\
\text { and Council of elders of } \\
\text { ethnic groups. }\end{array}$ \\
\hline
\end{tabular}




\begin{tabular}{|c|l|l|l|}
\hline 5 & $\begin{array}{l}\text { Conflicts between } \\
\text { indigenous peoples. }\end{array}$ & $\begin{array}{l}\text { In the USSR, multinational } \\
\text { republics were formed and for a } \\
\text { long time there was a "diffusion" } \\
\text { of indigenous peoples and their } \\
\text { habitats. }\end{array}$ & $\begin{array}{l}\text { Joint work of the } \\
\text { government, representatives } \\
\text { of land tenants and the } \\
\text { Council of elders of } \\
\text { indigenous peoples. }\end{array}$ \\
\hline 6 & $\begin{array}{l}\text { Conflicts between the } \\
\text { local population and } \\
\text { municipal authorities. }\end{array}$ & $\begin{array}{l}\text { The decision to lease certain plots } \\
\text { to specific economic agents is } \\
\text { made by the municipal } \\
\text { government. }\end{array}$ & $\begin{array}{l}\text { Improving auction } \\
\text { mechanisms and land law. }\end{array}$ \\
\hline 7 & $\begin{array}{l}\text { Conflicts between local } \\
\text { populations and large land } \\
\text { users. }\end{array}$ & $\begin{array}{l}\text { The "rural elite" received } \\
\text { significant areas of arable land } \\
\text { (up to 10,000 hectares) not by fair } \\
\text { means. }\end{array}$ & $\begin{array}{l}\text { Improving auction } \\
\text { mechanisms and land law. }\end{array}$ \\
\hline 8 & $\begin{array}{l}\text { Conflicts between } \\
\text { residents of the same } \\
\text { municipality. }\end{array}$ & $\begin{array}{l}\text { Uneven distribution of land and } \\
\text { access to communications often } \\
\text { create conflicts. }\end{array}$ & $\begin{array}{l}\text { Improving land law and } \\
\text { land resource allocation } \\
\text { mechanisms. }\end{array}$ \\
\hline 9 & $\begin{array}{l}\text { Not the adoption of } \\
\text { Federal and regional laws } \\
\text { "on land" by the local } \\
\text { populatio }\end{array}$ & $\begin{array}{l}\text { The problem is an adequate } \\
\text { public perception of land reform } \\
\text { to change the title of ownership } \\
\text { and land distribution mechanisms. }\end{array}$ & $\begin{array}{l}\text { There is currently no real } \\
\text { alternative to private land } \\
\text { ownership as a conceptual } \\
\text { basis for land reform. }\end{array}$ \\
\hline
\end{tabular}

Effective land use in the agricultural sector of mountain areas can be carried out under the following conditions:

- the processes of reforming land relations should be regulated by the state Commission with the participation of representatives of agricultural producers and local population at all stages of their implementation;

- the stages of land reform, methods and mechanisms for regulating land relations should have a scientific basis in order to ensure an optimal, effective and environmentally safe balance between nature and man;

- mechanisms of land ownership and land use should be formed taking into account the existing natural-climatic and economic-geographical conditions of the Republic, as well as the customs and traditions of indigenous peoples, the prevailing socio-economic and environmental conditions of agricultural production and labor culture.

The research was supported by the Russian Foundation of Basic Research, grant No. 20-010-00269A "A mechanism for mountainous regions development management on the basis of a the new architecture of local socio-economic systems" and grant No. 19-010-00577A "Problems of counteracting agency opportunism in multi-level systems with information asymmetry".

\section{References}

1. P. Bardhan, M. Dilip. AER, 100(4), 1572-1600. (2010); doi: 10.1257/aer.100.4.1572

2. H. Friedmann. The Journal of Peasant Studies, 46(5), 1096-1105. (2019); doi: $10.1080 / 03066150.2019 .1608684$

3. J. Clemens. AER, 103(3), 523-527. (2013); doi: 10.1257/aer.103.3.523

4. B. Daley, B. Green. AER, 110(2), 428-474. (2020); doi: 10.1257/aer.20181316

5. B. Cousins, I. Scoones. Journal of Peasant Studies, 37(1), 31-66 (2010); doi: 10.1080/03066150903498739

6. L. Alston, G. Libecap, B. Mueller. J. Environmental Economics \& Management. 39, 162-188 (2001). doi: 10.1006/jeem.1999.1103.

7. E. Ostrom. J. Institutional Econ., 3, 239-264. (2007). doi: $10.1017 / \mathrm{S} 1744137407000719$. 
8. E. Aryeetey, C. Udry. AER, 100(2), 130-134. (2010); doi: 10.1257/aer.100.2.130

9. Y. Qi, Y. Zhao, N. Hu, B. Jiang, H. Liu, C. Xiang. Asian Agricultural Research, 04(05), 139480. (2012); doi: 10.22004/ag.econ.139480

10. T. Schelling. The Strategy of Conflict. (Harvard UP, 1980)

11. M.V.Israilov. Competitiveness in the global world: Economics, science, and technology. 7-1(19), 131-133. (2016)

12. K. Burchardi, S. Gulesci, B. Lerva, M. Sulaiman. QJE, 134(1), 281-347. (2019); doi: 10.1093/qje/qjy023

13. A. Gurtuev, E. Derkach, Z. Ivanov. Izvestiya KBNC RAN, 4(78), 59-65. (2017)

14. S. Borras, J. Franco. J. Agragian Change, 10(1), 1-32. (2010); doi: 10.1111/j.14710366.2009.00243.X

15. Y. Liu, J. Li, Y. Yang. Land Use Policy, 74, 5-14. (2018);

doi: 10.1016/j.landusepol.2017.07.005 